\title{
Variation of hydraulic conductance of some adult conifers under natural conditions
}

\author{
A. Granier, N. Breda, J.P. Claustres and F. Colin
}

INRA, Laboratoire de Bioclimatologie et Ecophysiologie Forestières, Centre de Nancy, Champenoux BP 35,54280 Seichamps, France

\section{Introduction}

Along the soil-tree-atmosphere system, liquid flow of water can be modelled satisfactorily under many conditions by the Ohm's analog; in the liquid phase, the flow depends upon water potential gradients and hydraulic conductance from the soil to the mesophyll, which thus has an important significance for the description of water relations in trees.

We present here some evaluations of hydraulic conductance of trees growing under natural conditions. Data were collected from different experiments involving xylem water potential and sap flow measurements and we will analyze: 1) between-tree variability of liquid path conductance; and 2) the influence of soil drying on this parameter.

\section{Materials and Methods}

\section{Study sites}

The experiments were carried out in the stands described in Table I.

In the A. bornmulleriana stand, 4 trees were subjected to an imposed drought by withholding incident rainfall with a plastic roof covering the soil.

\section{Sap flow measurements}

A thermal device (Granier, 1985; 1987) allowed continuous measurement of sap flux density, which was integrated along a radial axis into the sapwood of the trunk. Total sap flow was evalu-

Table I. Description of the stands used in this study

\begin{tabular}{llllll}
\hline Species & Localization & $\begin{array}{l}\text { Age } \\
(y r)\end{array}$ & $\begin{array}{l}\text { Density } \\
(\text { stems/ha) }\end{array}$ & $\begin{array}{l}\text { Mean } h t \\
(m)\end{array}$ & $\begin{array}{l}\text { Sapwood } \\
\text { area } m^{2} / h a\end{array}$ \\
\hline $\begin{array}{l}\text { Picea abies } \\
\text { Pinus pinaster }\end{array}$ & $\begin{array}{l}\text { Nancy } \\
\text { Landes-de- }\end{array}$ & 21 & 4500 & 11.4 & 24.9 \\
Abies bornmulleriana & $\begin{array}{l}\text { Gascogne } \\
\text { Nancy }\end{array}$ & 23 & 2500 & 11.0 & 26.0 \\
\hline
\end{tabular}


ated through estimation of the sapwood area of the tree at flowmeter level. Measurements were made at $10 \mathrm{~s}$ intervals and data presented here are hourly averages.

\section{Xylem water potential}

This parameter was measured with a pressure chamber on 1 yr old spruce and fir twigs and on pine needles. Data are averages of 2-6 measurements made in sun-exposed and shaded parts of the crowns, on clear days at $2 \mathrm{~h}$ intervals; within-crown variability is not analyzed here, but the sampling procedure is very important, especially in dense stand conditions, where tree water potential shows a large variability.

\section{Estimation of hydraulic conductance $\mathrm{gL}$}

In order to compare trees of different species, age and stand conditions, we calculated the specific hydraulic conductivity as follows:

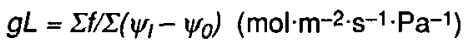

where $f=$ sap flux density (e.g., per unit of sapwood area $\left.\mathrm{mol} \cdot \mathrm{m}^{-2} \cdot \mathrm{s}^{-1}\right) ; \psi_{1}=x y l e m$ water potential $(\mathrm{Pa}) ; \psi_{0}=$ predawn water potential (Pa). Each summation was calculated over a complete daylight period at $2 \mathrm{~h}$ intervals.

\section{Results}

Fig. 1 shows an example of diurnal relationships between sap flux density and xylem water potential obtained on Abies from predawn to dusk. Loops are often noticed on clear days; they indicate nonsteady state water transfer with a time lag between water potential and sap flow, as reported also by Schulze et al., (1985) on spruce and larch. Nevertheless, Cohen et al. (1987) did not report this effect on citrus trees. The slopes of these relationship represent the inverse of $g L$, e.g., hydraulic resistance from the soil-root interface to the twig xylem.

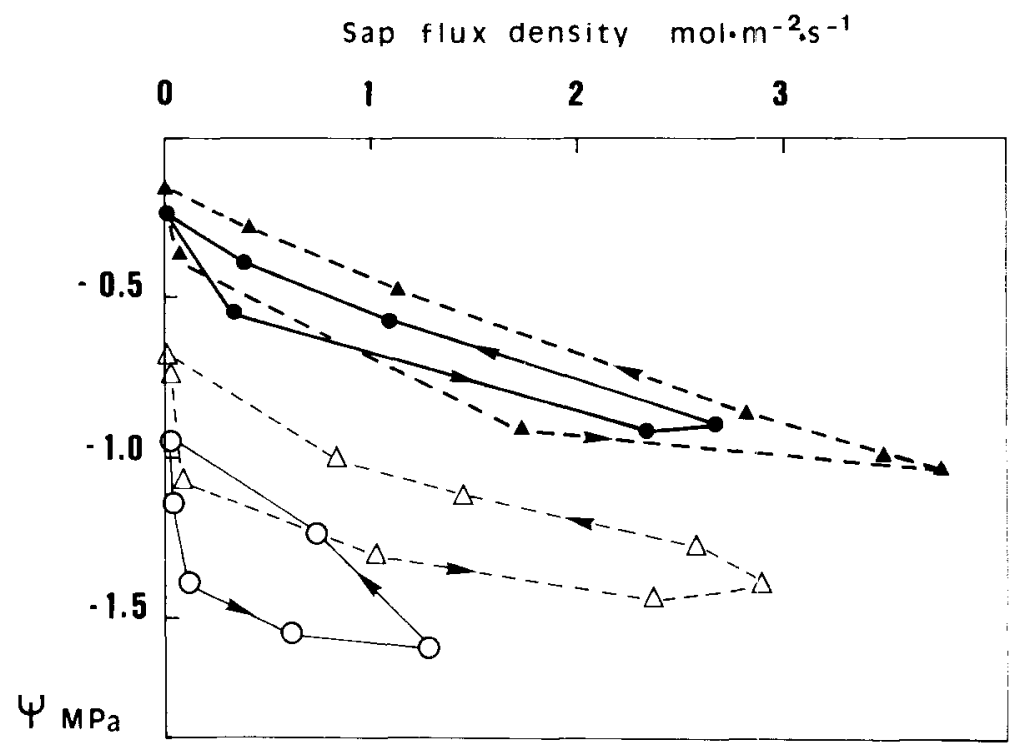

Fig. 1. Diurnal courses of xylem water potential $(\psi)$ as a function of sap flux density for 2 dominant $\boldsymbol{A}$. bornmulleriana trees on 2 cloudless days. Irrigated: $\boldsymbol{\Delta}$ : July $20, \psi_{0}=-0.18 \mathrm{MPa}$; : August $9, \psi_{0}=-0.25 \mathrm{MPa}$; waterstressed: $\Delta$ : July $20, \psi_{0}=-0.65 \mathrm{MPa}$; O: August $9, \psi_{0}=-0.97 \mathrm{MPa}$. 
Table II. Comparison of hydraulic conductance of the 3 species studied.

\begin{tabular}{|c|c|c|c|c|}
\hline Species & $\begin{array}{l}\psi_{0} \\
(M P a)\end{array}$ & $\begin{array}{l}\mathrm{gL} \times 10^{5} \\
\left(\mathrm{~mol} \cdot \mathrm{m}^{-2} \cdot \mathrm{s}^{-1} \cdot \mathrm{Pa}^{-1}\right)\end{array}$ & Remarks & \\
\hline P. Abies & -0.40 to -0.70 & $\begin{array}{l}0.31 \\
0.33 \\
0.33 \\
0.33 \\
0.34 \\
0.15 \\
0.07 \\
0.16 \\
0.17 \\
0.22\end{array}$ & $\begin{array}{l}\text { dominant } \\
\text { codominant } \\
\text { and } \\
\text { intermediate } \\
\text { isolated tree } \\
\text { rain-deprived } \\
\text { trees } \\
\text { dominant \& } \\
\text { codominant } \\
\text { trees }\end{array}$ & $\begin{array}{l}\text { water } \\
\text { stress }\end{array}$ \\
\hline P. pinaster & -0.40 & 0.40 & & no stress \\
\hline A. bornmulleriana & $\begin{array}{l}-0.18 \\
-0.64 \\
-0.97 \\
-1.14\end{array}$ & $\begin{array}{l}0.37 \\
0.27 \\
0.14 \\
0.11\end{array}$ & $\begin{array}{l}\text { dominant } \\
\text { trees }\end{array}$ & $\begin{array}{l}\text { no stress } \\
\text { increasing } \\
\text { water } \\
\text { stress }\end{array}$ \\
\hline
\end{tabular}

$g L$ (see eqn. 1) was calculated for the 3 coniferous species under different water stress conditions, as estimated by predawn water potential $\left(\psi_{0}\right)$ (Table II).

Table II shows that: 1) for the same species (see $P$. abies), between-tree variability depended upon crown class: $g L$ was rather constant for the dominant, codominant, intermediate and isolate trees. It was much lower for rain-deprived trees; 2) with increasing water stress (decreasing $\left.\psi_{0}\right), g L$ decreased continuously, as previously reported by Cohen et al. $(1987)$; 3) maximum values of $g L$ for the 3 studied species were comparable even under different stand and climate conditions: $0.34 \times 10^{-5} \mathrm{~mol} \cdot \mathrm{m}^{-2} \cdot \mathrm{s}^{-1} \cdot \mathrm{Pa}^{-1}$ for $P$. abies, $0.40 \times 10^{-5}$ for $P$. pinaster and 0.37 $\times 10^{-5}$ for $A$. bornmulleriana.

\section{Discussion}

The specific hydraulic conductivity can be interpreted in terms of leaf specific conductivity, assuming that in a closed stand there is a linear relationship between leaf area and sapwood cross-sectional area. Thus, the same values of $g L$ obtained for trees ranging from intermediate to dominant crown classes led us to think that mean vapor flux density across the leaf surfaces was rather constant between these trees. It was much lower for rain-deprived trees.

Water stress produced a decrease in $g L$ by a factor 3 between -0.18 and -1.14 $\mathrm{MPa}$ under our experimental conditions. Two hypotheses can be proposed: 1) drought increases the hydraulic resistance between soil and root; 2) drought reduces the hydraulic conductivity of sapwood.

Measurements of water potential at an intermediate level, especially at the lower part of the living crown, may be made on twigs of branches enclosed in a plastic bag (Hellkvist et al., 1974); they allow estimates of soil to mid-crown and mid-crown to twig hydraulic conductivity. A few measurements seems to indicate, as first results, that the $g L$ of the midcrown to twig path does not decrease as 
water stress increases $\left(g L=0.50 \times 10^{-5}\right.$ $\mathrm{mol} \cdot \mathrm{m}^{-2} \cdot \mathrm{s}^{-1} \cdot \mathrm{Pa}^{-1)}$, reinforcing the first hypothesis.

\section{References}

Cohen Y., Moreshet S. \& Fuchs M. (1987) Changes in hydraulic conductance of citrus trees following a reduction in wetted volume. Plant Cell Environ., 10, 53-57

Granier A. (1985) Une nouvelle méthode pour la mesure du flux de sève brute dans le tronc des arbres. Ann. Sci. For. 44, 1-14
Granier A. (1987) Evaluation of transpiration in a Douglas fir stand by means of sap flow measurements. Tree Physiol. 3, 309-320

Hellkvist J., Richards G.P. \& Jarvis P.G. (1974) Vertical gradients of water potential and tissue water relations in Sitka spruce trees measured with the pressure chamber. J. Appl. Ecol. 11, 637-667

Schulze E.D., Cermak J., Matyssek R., Penka M., Zimmermann R., Vasicek F., Gries W. \& Kucera J. (1985) Canopy transpiration and water fluxes in the xylem of the trunk of Larix and Picea trees - a comparison of xylem flow, porometer and cuvette measurements. Oecologia (Berlin) 66, 475-483 